\title{
The IMF and the Liberalization of Capital Flows
}

\author{
Joseph P. Joyce and Ilan Noy*
}

\begin{abstract}
We evaluate the claim that the International Monetary Fund precipitated financial crises during the 1990s, by pressuring countries to liberalize their capital accounts prematurely. Using data from a panel of developing economies from 1982-98, we examine whether the changes in the regime governing capital flows took place during participation in IMF programs. We find evidence that IMF program participation is correlated with capital account liberalization episodes during the 1990s. We verify the robustness of our results using alternative indicators of capital account openness. To determine whether decontrol was premature, we compare the economic and financial characteristics of countries that decontrolled during IMF programs with those of countries who did so independently, and find some evidence of IMF-led premature liberalizations.
\end{abstract}

\section{Introduction}

The Asian financial crisis of 1997/98 was followed by a wave of analyses that sought to determine its causes. One charge that emerged frequently was that the IMF had indirectly precipitated the crisis by pressuring countries to liberalize their capital accounts prematurely. Desai (2003, p. 217), for example, wrote: “... the IMF encouraged a disaster-prone policy gamble of capital account liberalization in these economies before they had put their 'structural house' in order." Similarly, Stiglitz (2002, p. 15) states that "... many of the policies that the IMF pushed, in particular, premature capital market liberalization, have contributed to global instability."

The IMF did play a role in the movement towards capital account decontrol that took place during the 1990s. Fund economists, like others, pointed out the advantages to developing economies of access to global capital markets. In September 1997, the IMF's policy-making Interim Committee proposed that the liberalization of capital flows be made a goal for the Fund's members-a proposal that was relegated to the sidelines and then dropped as the IMF sought to stem the massive capital outflows from East Asia.

However, the liberalization of capital flows was part of a global reaction against the Keynesian ideology of the post-World War II period. Under the Bretton Woods system, fixed exchange rates and capital controls protected countries from destabilizing external shocks. The counter-movement that began with the breakdown of the Bretton Woods system in the 1970s and accelerated in the 1980s sought to remove government controls and allow markets to operate freely. This trend in the developing economies was called the "Washington Consensus" by Williamson (1990), who included the decontrol of foreign direct investment (but not portfolio flows) in the list of policy measures.

\footnotetext{
* Joyce: Wellesley College, Wellesley, MA 02481. Tel: 781-283-2160; Fax: 781-283-2177; E-mail: jjoyce@ wellesley.edu. Noy: University of Hawaii, Honolulu, HI 96822. Tel: 808-956-7749; Fax: 808-956-4347; E-mail: noy@hawaii.edu. We thank Adam Honig, Michael Hutchison, Hiro Ito and Abdul de Guia Abiad for sharing their data, and audiences at the Bank of Korea, Korea University, the University of Hawaii, the Santa Cruz Center for International Economics (SCCIE), the ASSA meeting in Boston, and particularly our discussants Michael Dooley and Eric Bond. Noy wishes to thank the East West Center for financial support.
} 
Whether or not the IMF was indeed directly associated with the wave of capital account liberalization is an empirical issue that can be examined. We use data from a panel of developing economies during the period 1982-98 to determine whether the changes in the regime governing capital flows took place during IMF programs. We also investigate the impact of other factors, such as currency crises, that may have affected the decision to decontrol. In addition, to assess whether liberalization was premature, we compare conditions in countries that liberalized while participating in IMF programs with those that decontrolled independently.

While other studies have investigated the conditions that accompany the use (or absence) of capital controls, this paper explicitly addresses the issue of the timing of the change from a closed to an open capital regime, and is the first to use rigorous testing methods to investigate the linkage between that decision and the IMF. Our results are significant for a clearer understanding of the role of the Fund in capital account liberalization, as well as economic reform in general.

The next section reviews the IMF's position on the use of capital controls. Section 3 summarizes the literature on capital controls. Section 4 outlines the data and methodology used in the empirical analysis. Section 5 presents our results, and also a comparison of economic conditions in countries that liberalized with and without IMF programs. The last section offers our conclusions.

\section{IMF and Capital Controls}

The IMF's Articles of Agreement (Article VI, Section 1a) allowed countries to retain capital controls, and stipulated that countries could not draw upon the Fund's resources to meet a "... large or sustained outflow of capital." Private capital movements, however, began to grow in size and importance in the late 1950s, and private capital flows were an important component in the adjustment process to the oil shock of 1973. The developed countries removed their restrictions on capital flows during the 1970s and 1980s. A number of countries in Asia moved in the same direction during this period, and were followed in turn by several South American economies at the end of the 1980s. African and Middle Eastern countries did not move as far in opening their capital accounts. ${ }^{1}$

Using archival sources, Abdelal (2007) has traced the evolution of the IMF's position on this issue, which he shows emanated from the IMF's management. Within the IMF, the leading advocates of decontrol were former Managing Director Michel Cadmessus, and Manuel Guitián, then director of the Monetary and Exchange Affairs Department. Guitián (1995, p. 86), for example, wrote that “. . . a strong case can be made in support of rapid and decisive liberalization of capital transactions."

While capital decontrol was never an explicit goal of the IMF, and therefore could not be made part of the conditions associated with Fund programs, the IMF did at times advocate movement towards liberalization. An IMF Occasional Paper (1995, p. 6) by a staff team, for example, observed: “... the institution has in some cases encouraged developing countries to open their economies to foreign capital inflows, and to liberalize restrictions on capital account transactions."

The IMF's Independent Evaluation Office has examined the Fund's position on capital account liberalization during the 1990s. The IEO (2005, p. 51) found that “... a number of IMF-supported programs with some of the sample countries included references to aspects of capital account liberalization in the letters of intent (LOIs) or accompanying policy memorandums ..." But the IEO's report (2005, p. 92) concluded that "In none of the program cases examined did the IMF require capital 
account liberalization as formal conditionality, although aspects of it were often included in the authorities' overall policy package presented to the IMF."

Leiteritz (2005) ties the shift in the IMF's position on capital account decontrol to the US policy of promoting access for US financial firms to foreign markets. Similarly, DeLong and Eichengreen (2002, p. 237) claim that the Clinton administration's "... support for capital account liberalization flowed naturally from its belief in free and open markets ...", as well as a belief that controls provided opportunities for corruption and were difficult to administer. Abdelal (2007), however, points out that the private financial sector in the US (Wall Street) and the Institute for International Finance, which represents major banks, was much less enthusiastic than the Clinton administration about the transition towards capital decontrol.

This movement culminated in the proposal at the IMF's 1997 Annual Meeting to make the liberalization of capital movements one of the IMF's goals, and to extend the Fund's jurisdiction to this area. The events in Asia, however, overshadowed the discussion, and increased challenges to the proposed Amendment. US Congressional opposition and the Russian crisis combined to terminate the proposal in 1998.

\section{Determinants of Capital Controls}

There have been a number of studies of the determinants of capital controls; Eichengreen (2001) provides a survey of the literature. The dependent variable in the majority of these studies was a binary indicator of the presence of capital controls available from the IMF, and an appropriate estimation model utilized to test the significance of proposed determinants of capital controls. The results have varied by period and by level of development.

However, a number of empirical relationships seem robust to alternative specifications. Richer countries, as measured by per-capita GDP, are less likely to maintain controls, as are countries with independent central banks. Countries with larger trade sectors are more likely to have liberalized capital flows, as have been countries with larger reserve/import coverage. Some of the earlier studies reported that left-wing governments were more inclined to maintain controls, as were governments with large consumption/GDP shares.

A change in regulation may also occur in response to some discrete event, such as a crisis. The direction of the change in such an occurrence, however, is ambiguous. On the one hand, a government may impose controls in order to stem capital outflows; on the other hand, capital account liberalization may serve as a signaling device for government officials to establish their reliability with global capital markets.

Haggard and Maxfield (1993) describe a sequence in which a populist government enacts expansionary economic policies, which result in capital flight. The government imposes trade and capital controls, but a crisis ensues. A new team of policymakers emerges, which seeks to enhance their credibility by liberalizing the capital account. Convertibility signals the government's intention to undertake reforms, and also constrains its ability to engage in budget deficit financing. Haggard and Maxfield (1996) point out that there will be domestic coalitions on both sides of the issue of capital account liberalization. Crises are likely to increase the power of those in favor of liberalization.

Rowlands (1999) tested Haggard and Maxfield's (1993,1996) hypothesis. His results showed that liberalization occurred when the current account balance was improving, foreign reserves rising and the exchange rate appreciating. He interpreted these results as refuting the hypothesis, but also attributed the disparity in results to differences in 
the definition of liberalization and measurement issues. Simmons and Elkins (2004), on the other hand, found that currency crises were associated with capital account liberalization.

There has been relatively little econometric evidence on the impact of the IMF on the process of decontrol. Simmons and Elkins (2004) found that the use of IMF credit was associated with capital account restrictions, which they attribute to the existence of capital flight at the times of the adoption of a Fund program. Abiad and Mody (2005) reported that IMF programs have a strong impact on financial reform in countries that are highly repressed, but this effect declines as repression is diminished.

These two hypotheses-that decontrol takes place during an IMF program or that decontrol is a form of signaling during a crisis-are not mutually exclusive. Governments may adopt IMF programs in response to crises in the external sector, and the program itself serves as a type of commitment device. On the other hand, not all countries facing crises adopt Fund programs, and not all IMF programs are put into place in response to currency crises. In the analysis below, we differentiate between these two accounts of the process of capital decontrol.

\section{Data and Methodology}

We begin the sample period in 1982, and obtained data for 53 developing and emerging market economies. ${ }^{2}$ As this paper's focus is on the linkages between participation in IMF programs and the liberalization of the capital account, we first discuss the data on IMF programs and capital account controls. We then outline the methodology we use in order to identify the impact of the IMF on the decision to liberalize. Details on the sources of the remaining data are listed in Appendix A.

\section{IMF Programs}

The main IMF facilities designed to meet balance of payments stabilization needs are the Stand-By Arrangement (SBA) and the Extended Fund Facility (EFF), while those designed for longer-term development goals have been the concessionary programs, the Structural Adjustment Facility and Enhanced Structural Adjustment Facility (SAF and ESAF), which have been renamed as the Poverty Reduction and Growth Facility (PRGF). In general, Fund members can access credit tranches beyond the first $25 \%$ of their allowed quota only after a program agreement is signed between the IMF and the member's government. Conditionality ties the disbursement of credit in phases to the fulfillment of policies that the government has agreed to implement. We, therefore, define an IMF program as a signed agreement between the IMF and a sovereign government for a future distribution of resources. ${ }^{3}$

The distribution of IMF programs by type (nonconcessionary/concessionary), by region, and by decade, is shown in Table 1 . There were 241 non-concessionary and 74 concessionary programs initiated and approved for our sample between 1982 and 1999. The non-concessionary stabilization programs were primarily directed to Latin America (27\% of program approvals) and Africa (35\%). Predictably, given the poverty in the region, African recipients dominate the long-term concessionary structural programs with $61 \%$ of those programs.

\section{Capital Controls}

We conduct our initial analysis using the binary measure for restrictions on the capital account taken from the IMF's Annual Report on Exchange Arrangements and 
Table 1. Sample Descriptive Statistics for IMF and Liberalization Variables

\begin{tabular}{lccccc}
\hline & $\begin{array}{c}\text { Non-concessionary } \\
\text { programs }\end{array}$ & $\begin{array}{c}\text { Concessionary } \\
\text { programs }\end{array}$ & $\begin{array}{c}\text { Liberalized } \\
\text { capital } \\
\text { account }\end{array}$ & $\begin{array}{c}\text { Average for } \\
\text { Miniane } \\
\text { index }\end{array}$ & $\begin{array}{c}\text { Average for } \\
\text { Chinn- } \\
\text { Ito index }\end{array}$ \\
\hline Latin America & 65 & 6 & $31 \%$ & 0.16 & -0.24 \\
East Asia & 20 & 4 & $34 \%$ & 0.42 & 0.91 \\
Middle East & 7 & 1 & $48 \%$ & & 0.55 \\
Africa & 85 & 45 & $1 \%$ & & -0.67 \\
Other & 64 & 18 & $11 \%$ & & -0.46 \\
1980s & 74 & 32 & $16 \%$ & 0.21 & -0.56 \\
1990s & 67 & 42 & $19 \%$ & 0.28 & 0.08 \\
\hline
\end{tabular}

Note: Non-concessionary programs include Stand-By Arrangements and Extended Fund Facilities. Concessionary programs include the Structural Adjustment Facility and the Enhanced Structural Adjustment Facility. The third column reports the number of country/year observations with liberalized accounts as a percent of total observations. The fourth and fifth columns present averages for the Miniane and Chinn-Ito Indices on the degree of capital account liberalization (see text for details).

Exchange Restrictions (AREAR). This measure is the only internationally comparable indicator of the legal framework that governs the capital account available for a large sample of countries on an annual basis. The IMF changed its methodology after 1996 to provide a more detailed measure of the rules and restrictions governing the capital account. Glick and Hutchison (2005) extended the original AREAR series through 1998 , using the descriptions of country practices provided in the IMF's annual reports, and we incorporate their data into ours. ${ }^{4}$ In Tables 2 and 3, we use the $A R E A R$ data to construct a binary indicator of capital account liberalization that equals zero in the preliberalized capital accounts, and unity in the year of liberalization and the previous year $(t$ and $t-1)$.

To examine the robustness of our results, we also used two other measures of capital account openness. The first was developed by Miniane (2004), who utilized the new criteria developed by the IMF, and extended these backwards to 1983 for a set of developing and developed countries. From this detailed data, Miniane (2004) constructed an index of openness that ranges from zero to one. We transformed this index so that one signifies a completely unrestricted capital account. There are data for 14 developing countries in this data set.

The second indicator of capital account openness was developed by Chinn and Ito (2006, 2007). They used the data reported in the AREAR on the existence of multiple exchange rates, restrictions on the current and capital accounts, and requirements to surrender export proceeds to capture the intensity of controls. Their index of openness is the first standardized principal component of the four variables above, and ranges from -2.5 in the case of full control to 2.5 in the case of complete liberalization. The data were available for 108 developed and developing countries for 1970-2000; we utilize only data for developing countries for 1982-98.

Descriptive statistics for the $A R E A R$, Miniane and Chinn-Ito data are provided in Table 1. Appendix B in the working paper version (Joyce and Noy, 2005) lists the countries that decontrolled capital flows and the dates of liberalization in the three data sets. Alternative measures that examine the de facto openness of the capital account are also occasionally used in research on openness in international capital markets, but 
Table 2. Political and Economic Determinants of Capital Controls (onset AREAR Data)

\begin{tabular}{|c|c|c|c|}
\hline & Equation (2.1) & Equation (2.2) & Equation (2.3) \\
\hline RES & $\begin{array}{l}-0.05 \\
(1.07)\end{array}$ & $\begin{array}{l}-0.05 \\
(1.09)\end{array}$ & $\begin{array}{c}-0.04 \\
(1.07)\end{array}$ \\
\hline TRAD & $\begin{array}{c}-0.01^{*} \\
(1.68)\end{array}$ & $\begin{array}{c}0.00 \\
(1.48)\end{array}$ & $\begin{array}{c}0.00 \\
(0.87)\end{array}$ \\
\hline GCON & $\begin{array}{c}-0.04 \\
(1.10)\end{array}$ & $\begin{array}{c}-0.04 \\
(1.18)\end{array}$ & $\begin{array}{l}-0.06^{* *} \\
(2.35)\end{array}$ \\
\hline STDBT & $\begin{array}{c}-0.02^{*} \\
(1.59)\end{array}$ & $\begin{array}{c}-0.03^{*} \\
(1.92)\end{array}$ & $\begin{array}{l}-0.02 \\
(1.44)\end{array}$ \\
\hline UNITY & $\begin{array}{c}-0.71^{*} \\
(1.64)\end{array}$ & $\begin{array}{l}-0.75^{* *} \\
(2.01)\end{array}$ & $\begin{array}{l}-0.78^{* * *} \\
(2.69)\end{array}$ \\
\hline GBUD & $\begin{array}{r}0.07 * \\
(1.85)\end{array}$ & $\begin{array}{r}0.07 * \\
(1.91)\end{array}$ & $\begin{array}{c}0.04 \\
(1.46)\end{array}$ \\
\hline GDPCAP & $\begin{array}{c}0.06 \\
(1.07)\end{array}$ & $\begin{array}{c}0.06 \\
(1.15)\end{array}$ & $\begin{array}{c}0.07 \\
(1.53)\end{array}$ \\
\hline FINT & $\begin{array}{l}-0.12^{*} \\
(1.80)\end{array}$ & $\begin{array}{l}-0.14 * * \\
(2.22)\end{array}$ & $\begin{array}{l}-0.06 \\
(1.29)\end{array}$ \\
\hline $1990 \mathrm{~s}$ & $\begin{array}{c}0.44 \\
(1.42)\end{array}$ & $\begin{array}{c}0.46 \\
(1.54)\end{array}$ & $\begin{array}{c}0.34 \\
(1.50)\end{array}$ \\
\hline CURCR & $\begin{array}{c}0.13 \\
(0.42)\end{array}$ & $\begin{array}{c}0.16 \\
(0.58)\end{array}$ & \\
\hline CORPT & $\begin{array}{c}0.15 \\
(0.92)\end{array}$ & $\begin{array}{c}0.16 \\
(1.04)\end{array}$ & \\
\hline CURAC & $\begin{array}{c}0.00 \\
(0.16)\end{array}$ & & \\
\hline INF & $\begin{array}{c}0.00 \\
(0.56)\end{array}$ & & \\
\hline BANCRI & $\begin{array}{c}0.25 \\
(0.88)\end{array}$ & & \\
\hline EXREG & $\begin{array}{c}-0.20 \\
(0.73)\end{array}$ & & \\
\hline LEFT & $\begin{array}{c}-0.13 \\
(0.45)\end{array}$ & & \\
\hline DEM & $\begin{array}{c}0.02 \\
(0.07)\end{array}$ & & \\
\hline ELECT & $\begin{array}{c}0.01 \\
(0.34)\end{array}$ & & \\
\hline Observations & 503 & 516 & 769 \\
\hline Pseudo $\mathrm{R}^{2}$ & 0.54 & 0.48 & 0.39 \\
\hline Akaike IC & 0.33 & 0.30 & 0.27 \\
\hline
\end{tabular}

Note: The dependent variable denotes the onset of capital account liberalization: $0=$ non-liberalized capital account or $1=$ liberalization during a two-year window. For definitions of variables, see Appendix. $T$-statistics in parentheses; significance levels are $10 \% *, 5 \% * *$ and $1 \% * * *$. 
Table 3. The IMF and Capital Controls (onset AREAR Data)

\begin{tabular}{|c|c|c|c|c|c|}
\hline & $\begin{array}{c}\text { Equation } \\
\text { (3.1) }\end{array}$ & $\begin{array}{c}\text { Equation } \\
(3.2)\end{array}$ & $\begin{array}{c}\text { Equation } \\
\text { (3.3) }\end{array}$ & $\begin{array}{c}\text { Equation } \\
(3.4)\end{array}$ & $\begin{array}{c}\text { Equation } \\
(3.5)\end{array}$ \\
\hline CURCR & $\begin{array}{c}-0.15 \\
(0.59)\end{array}$ & $\begin{array}{l}-0.23 \\
(0.76)\end{array}$ & $\begin{array}{c}0.00 \\
(0.01)\end{array}$ & $\begin{array}{c}-0.06 \\
(0.21)\end{array}$ & $\begin{array}{c}0.00 \\
(0.06)\end{array}$ \\
\hline $1990 \mathrm{~s}$ & $\begin{array}{c}0.22 \\
(0.89)\end{array}$ & $\begin{array}{c}0.10 \\
(0.38)\end{array}$ & & $\begin{array}{c}0.23 \\
(0.92)\end{array}$ & $\begin{array}{c}0.23 \\
(0.92)\end{array}$ \\
\hline NEWIMF & $\begin{array}{l}0.73 * * * \\
(2.61)\end{array}$ & $\begin{array}{l}0.79 * * \\
(2.49)\end{array}$ & $\begin{array}{l}0.91 * * \\
(2.52)\end{array}$ & $\begin{array}{l}0.81 \text { *** } \\
(2.83)\end{array}$ & \\
\hline IMFSIZE & & & & $\begin{array}{c}0.01 \\
(1.54)\end{array}$ & \\
\hline NEWIMF*CURCR & & & & & $\begin{array}{c}0.30 \\
(0.70)\end{array}$ \\
\hline NEWIMF*NOCURCR & & & & & $\begin{array}{l}1.07^{* * * *} \\
(2.99)\end{array}$ \\
\hline Observations & 623 & 494 & 281 & 623 & 623 \\
\hline Pseudo $\mathrm{R}^{2}$ & 0.40 & 0.38 & 0.36 & 0.42 & 0.42 \\
\hline Akaike IC & 0.30 & 0.34 & 0.45 & 0.30 & 0.30 \\
\hline
\end{tabular}

Note: The dependent variable denotes the onset of capital account liberalization: $0=$ non-liberalized capital account or $1=$ liberalization during a two-year window. Additional control variables are those of equation (3.3). The sample in equation (5.2) is restricted to countries with a GDP per capita of $\$ 1500$ and above (PPP adjusted), while the sample in equation (5.3) is restricted to the 1990s. For definitions of variables, see Appendix. $T$-statistics in parentheses; significance levels are $10 \% *, 5 \% * *$ and $1 \% * * *$.

these are not directly relevant to our interest in the impact of the IMF on a government's decision to change its de jure treatment of capital flows.

\section{Estimation Methodology}

The $A R E A R$ data on capital account controls and our indicator of capital account liberalization, which is the measure we focus on, are both binary. Since we are interested in isolating the IMF's impact on the decision to liberalize the capital account, we estimate a multivariate probit specification of the determination of the openness of the capital account. We postulate a probit model of this form:

$$
\left[\operatorname{prob}\left(C A P L I B_{i t}=1\right)\right]=F\left(\alpha_{i}+\beta X_{i t}+\gamma P_{i t}+\delta I M F_{i t}\right)
$$

where $C A P L I B$ is a binary variable denoting the de jure openness of the capital account, $\alpha_{i}$ is the country-fixed-effect, $X$ is a vector of macroeconomic and financial variables, $P$ is a vector of political and institutional measures, and $I M F$ is a measure denoting participation in an IMF program. In order to make the signs of the coefficients using the data sets comparable, we transform the IMF's $A R E A R$ data so that the dependent variable takes the value of unity when there is an unregulated capital account and zero otherwise.

We first specify a series of benchmark regressions with macroeconomic and political control variables, based on previous work. We started with a full set of control variables, and incrementally delete the least significant variable verifying each step with a reduction in the Akaike Information Criterion (AIC). We then augment these variables with various measures of participation in IMF programs. The estimations include country fixed effects (not reported) and a correction for heteroscedasticity. 
The Miniane (2004) and the Chinn and Ito (2006, 2007) capital account openness indices, which we use to examine the robustness of our results, are continuous. The continuous measures of capital account openness (the 0-1 Miniane index and the Chinn-Ito $-2.5-+2.5$ index) ignore differences in the degree of openness or repression that occur for those observations that occupy the extreme ends of these measures. For these indices, we use similar specifications to those in the previous tables for the $A R E A R$ measures, but with a Tobit estimation methodology, since the data are censored.

\section{Results}

\section{Determinants of Liberalization}

Table 2 reports the results for the benchmark regressions, using the indicator of capital control liberalization derived from the $A R E A R$ data as the dependent variable, and incrementally reducing the list of control variables as described in the previous section. In the final specification, equation (2.3), few of the variables were significant for the standard $10 \%$ threshold. A higher level of government consumption was found to be linked to the use of controls, which is most likely due to the government's need to levy taxes. This result was consistent with those reported by Glick and Hutchison (2005), Grilli and Milesi-Ferretti (1995) and Milesi-Ferretti (1998).

Coefficients for the other economic variables were not statistically significant in the determination of liberalization. However, if the original $A R E A R$ data indicating the existence or absence of controls are used as the dependent variable (as in Table 4), a number of economic variables were significant in line with previous research. ${ }^{5}$ The binary indicator of a currency crisis is not significant in any of the specifications.

Several political variables were also initially included in the benchmark regression. An increase in government unity, measured by the sum of the squared seat shares of all parties in the government (a Herfindahl index), was associated with lower likelihood of liberalization, and this effect was significant at the $1 \%$ level. This result suggests that decontrol occurs when the government is divided, and may not be able to withstand external pressure. This may also be related to the finding reported by Glick and Hutchison (2005), Grilli and Milesi-Ferretti (1995) and Milesi-Ferretti (1998), that an increase in the number of government changes was inversely related to the presence of capital controls.

Corruption was not statistically associated with the act of liberalization, but results not reported here (see Joyce and Noy, 2005) were found to be inversely related to the level of openness to capital flows and significant at the $5 \%$ significance level, indicating that a government can extract rents from these controls. The remaining political variables, including indicators of left-wing partisanship, democracy, and the holding of elections, were never significant, and were subsequently dropped. A dummy variable for the 1990s was positive, but insignificant in the initial benchmark regression.

Table 3 uses the same dependent variable as in Table 2. Observations in which the capital account was already open for more than two years were discarded. To the specification reported in equation (2.3) we now add our focus variables, the indicator of currency crises and various variables that proxy for IMF influence.

The 1990s variable continues to have a positive but insignificant coefficient, while the currency crisis coefficient is negative and insignificant. These results do not change in subsequent specifications. In equation (3.1), we add a measure of participation in an IMF program, NEWIMF, which indicates the initiation of an IMF program. The 
Table 4. The IMF and Capital Controls (level AREAR Data)

\begin{tabular}{|c|c|c|c|c|c|c|}
\hline & $\begin{array}{c}\text { Equation } \\
\text { (4.1) }\end{array}$ & $\begin{array}{c}\text { Equation } \\
(4.2)\end{array}$ & $\begin{array}{c}\text { Equation } \\
\text { (4.3) }\end{array}$ & $\begin{array}{c}\text { Equation } \\
(4.4)\end{array}$ & $\begin{array}{c}\text { Equation } \\
(4.5)\end{array}$ & $\begin{array}{c}\text { Equation } \\
\quad(4.6)\end{array}$ \\
\hline CURCR & $\begin{array}{l}-0.26 \\
(1.47)\end{array}$ & $\begin{array}{l}-0.26 \\
(1.43)\end{array}$ & $\begin{array}{l}-0.65^{* *} \\
(2.15)\end{array}$ & $\begin{array}{c}-0.42 \\
(1.46)\end{array}$ & $\begin{array}{l}-0.26 \\
(1.46)\end{array}$ & $\begin{array}{l}-0.26 \\
(1.45)\end{array}$ \\
\hline 1990s & $\begin{array}{l}-0.28 * * \\
(1.98)\end{array}$ & $\begin{array}{l}-0.76^{* * * *} \\
(3.61)\end{array}$ & & $\begin{array}{l}-0.28^{* *} \\
(1.98)\end{array}$ & $\begin{array}{l}-0.28 * * \\
(2.09)\end{array}$ & $\begin{array}{l}-0.28^{* * *} \\
(1.99)\end{array}$ \\
\hline IMF & $\begin{array}{l}0.27 * * \\
(1.96)\end{array}$ & & $\begin{array}{l}0.67 * * * \\
(3.26)\end{array}$ & & & $\begin{array}{l}0.30 \text { *** } \\
(2.06)\end{array}$ \\
\hline IMF80s & & $\begin{array}{c}-0.18 \\
(0.89)\end{array}$ & & & & \\
\hline IMF90s & & $\begin{array}{l}0.70 * * * \\
(3.56)\end{array}$ & & & & \\
\hline IMF*CURCR & & & & $\begin{array}{c}0.50 \\
(1.45)\end{array}$ & & \\
\hline IMF*NOCURCR & & & & $\begin{array}{c}0.23 \\
(1.54)\end{array}$ & & \\
\hline SRIMF & & & & & $\begin{array}{c}0.12 \\
(0.88)\end{array}$ & \\
\hline LRIMF & & & & & $\begin{array}{c}0.37 * \\
(1.81)\end{array}$ & \\
\hline IMFSIZE & & & & & & $\begin{array}{l}-1.04 \\
(0.65)\end{array}$ \\
\hline Observations & 649 & 649 & 361 & 649 & 649 & 649 \\
\hline Pseudo $\mathrm{R}^{2}$ & 0.67 & 0.63 & 0.86 & 0.67 & 0.64 & 0.65 \\
\hline Akaike IC & 0.76 & 0.75 & 0.80 & 0.77 & 0.77 & 0.77 \\
\hline
\end{tabular}

Note: Dependent variable is either 0 (full controls) or 1 (no controls). T-statistics in parentheses; significance levels are $10 \% *, 5 \% * *$ and $1 \% * * *$. Additional control variables included in all specifications are RES, TRAD, GCON, STDBT, CORPT, UNITY, and INFL. For definitions of variables, see Appendix. The sample in equation (4.3) is restricted to the 1990s.

coefficient is positive and significant at the $1 \%$ level; a country was more likely to liberalize its capital account immediately after an agreement was signed with the IMF. The sample used for the estimation of equation (3.2) consisted of developing countries with a GDP per capita of at least $\$ 1,500$. The coefficient on the IMF program variable is again positive, only slightly bigger and significant at the $5 \%$ level. The sample period is restricted to the 1990s for equation (3.3), and the IMF program variable is now larger and significant at the $5 \%$ level.

We introduced the size of the IMF program scaled by GDP (IMFSIZE) as an independent variable in equation (3.4), to test whether the IMF had more leverage in cases of larger programs or a larger stake in pushing for reform. The coefficient has a "plausible" positive sign, and is almost significant at the conventional $10 \%$ level. In equation (3.5), we used two interactive variables, the new IMF program and the currency crisis variable, and the IMF program and a no-crisis variable. The coefficient on the latter is more than three times as large and statistically significant at the $1 \%$ level, suggesting that countries were more likely to liberalize during an IMF program in the absence of a crisis.

In Table 4, we test the robustness of our results using a different dependent variable, the nature of the capital account regime in levels using the $A R E A R$ data. The pseudo 
$\mathrm{R}^{2}$ rises in the levels equations from $0.36-0.42$ (in Table 3 ) to $0.63-0.86$ in the specifications in Table 4. However, using the AREAR data in levels to capture the effect of IMF programs on the actual transition to a liberalized capital regime is an imprecise procedure. The existence of IMF programs can be consistent with such a regime, but may not have been a direct determinant of the changeover. Therefore, we treat these specifications only as an examination of the robustness of our results even though the goodness-of-fit measure of these equations is much higher.

We again report only the results for the variables of interest. ${ }^{6}$ In equation (4.1), a dummy variable reflecting the existence of an IMF program is added, and appears with a positive sign: those countries that adopted IMF programs were less likely to have controls. The 1990s variable now has a significant negative coefficient, which indicates that, after controlling for all the other effects we identified, there were many countries that maintained controls during the 1990s, despite an apparent wave of deregulation. The coefficient of the indicator of currency crises is generally insignificant and negative.

In the following equation, we replaced the one IMF variable with two indicators, one for IMF programs in the 1980s and one for programs in the 1990s. The coefficient associated with the latter variable is significant at the $1 \%$ level, and is almost 2.5 times bigger than the IMF program coefficient in the previous specification, whereas the 1980 s program variable is not significant. Countries with IMF programs in the 1990s were significantly less likely to have controls, even though the negative coefficient on the 1990s variable shows that controls were more common in other countries during the decade.

In equation (4.3), we limit the observations to the 1990s. The IMF program variable continues to be positive and strongly significant, and maintains the same magnitude as that reported in equation (4.2). Moreover, the currency crisis variable, which was not significant in either of the first two specifications, has a negative sign here which is significant. Countries with currency crises during the decade of the 1990s were more likely to maintain controls. ${ }^{7}$

We interact the IMF program variable with currency crisis and non-crisis indicators in equation (4.4). Neither has a significant coefficient, although the IMF-crisis variable has a coefficient that is twice as big as the IMF-non-crisis variable.

In equation (4.5), we differentiate between the non-concessionary IMF programs, such as the Stand-by Arrangements, and the long-run facilities, such as the Enhanced Structural Adjustment Facility. Both coefficients are positive, but the coefficient of the concessionary programs is significant at the $10 \%$ level, and is three times as big as the coefficient on the non-concessionary program indicator, which is not statistically significant. This result is plausible, as capital account liberalization is consistent with the structural adjustment policies that are part of the concessionary facilities.

In equation (4.6), we add the size of the IMF program relative to GDP as a variable. The coefficient is not significant for program size, but the binary IMF program variable retains its magnitude and significance.

\section{Tests of Robustness}

In the remaining tables, we use the two other indicators of liberalization, those of Miniane (2004) and Chinn-Ito (2006, 2007). Table 5 replicates the benchmark specifications of Table 2, using the Miniane data in equations (5.1) and (5.2), and the ChinnIto data in equations (5.3) and (5.4). A Tobit estimation is used to deal with the bias in the least squares estimation procedures with censored data. 
Table 5. Political and Economic Determinants of Capital Controls (Alternative Indices)

\begin{tabular}{|c|c|c|c|c|}
\hline & \multicolumn{2}{|c|}{ Miniane index } & \multicolumn{2}{|c|}{ Chinn-Ito index } \\
\hline & Equation (5.1) & Equation (5.2) & Equation (5.3) & Equation (5.4) \\
\hline RES & $\begin{array}{l}-0.04 * * * \\
(6.08)\end{array}$ & $\begin{array}{l}-0.05 * * * \\
(6.87)\end{array}$ & $\begin{array}{l}0.04 * * \\
(2.13)\end{array}$ & $\begin{array}{l}0.04 * * * \\
(2.72)\end{array}$ \\
\hline TRAD & $\begin{array}{l}-0.00 * * * \\
(2.94)\end{array}$ & $\begin{array}{l}-0.00 * * * \\
(3.90)\end{array}$ & $\begin{array}{l}0.01 * * * \\
(8.32)\end{array}$ & $\begin{array}{l}0.01 \text { *** } \\
(10.27)\end{array}$ \\
\hline GCON & $\begin{array}{l}-0.01 * * * \\
(2.98)\end{array}$ & $\begin{array}{l}-0.02^{* * * *} \\
(3.70)\end{array}$ & $\begin{array}{l}-0.06^{* * *} \\
(4.01)\end{array}$ & $\begin{array}{l}-0.07^{* * *} \\
(7.08)\end{array}$ \\
\hline STDBT & $\begin{array}{l}-0.01 * * * \\
(3.99)\end{array}$ & $\begin{array}{l}-0.01^{* * * *} \\
(3.88)\end{array}$ & $\begin{array}{l}0.03^{* * * *} \\
(4.14)\end{array}$ & $\begin{array}{l}0.03 * * * \\
(7.03)\end{array}$ \\
\hline UNITY & $\begin{array}{l}-0.19 * * * \\
(3.72)\end{array}$ & $\begin{array}{l}-0.21 * * * \\
(4.68)\end{array}$ & $\begin{array}{l}-0.27 \\
(1.44)\end{array}$ & $\begin{array}{l}-0.28^{* * *} \\
(2.30)\end{array}$ \\
\hline GBUD & $\begin{array}{l}0.01 * * \\
(2.04)\end{array}$ & $\begin{array}{l}0.01 * * \\
(2.44)\end{array}$ & $\begin{array}{c}-0.01 \\
(0.45)\end{array}$ & \\
\hline GDPCAP & $\begin{array}{l}0.02 * * \\
(2.41)\end{array}$ & $\begin{array}{l}0.02 * * * \\
(2.66)\end{array}$ & $\begin{array}{c}0.02 \\
(0.53)\end{array}$ & \\
\hline FINT & $\begin{array}{l}-0.03 * * * \\
(4.75)\end{array}$ & $\begin{array}{l}-0.03^{* * * *} \\
(4.97)\end{array}$ & $\begin{array}{l}-0.14 * * * \\
(4.68)\end{array}$ & $\begin{array}{l}-0.11^{* * * *} \\
(6.07)\end{array}$ \\
\hline $1990 \mathrm{~s}$ & $\begin{array}{c}0.06^{*} \\
(1.60)\end{array}$ & $\begin{array}{c}0.05^{*} \\
(1.60)\end{array}$ & $\begin{array}{l}0.35^{* * * *} \\
(2.78)\end{array}$ & $\begin{array}{l}0.29 * * * \\
(3.19)\end{array}$ \\
\hline CURCR & $\begin{array}{l}-0.04 \\
(0.97)\end{array}$ & $\begin{array}{l}-0.04 \\
(1.17)\end{array}$ & $\begin{array}{l}-0.21 \\
(1.49)\end{array}$ & $\begin{array}{l}-0.27 * * \\
(2.52)\end{array}$ \\
\hline CORPT & $\begin{array}{l}-0.01 \\
(0.81)\end{array}$ & & $\begin{array}{l}-0.07 \\
(1.08)\end{array}$ & \\
\hline CURAC & $\begin{array}{c}0.00 \\
(0.32)\end{array}$ & & $\begin{array}{r}0.02 * \\
(1.65)\end{array}$ & $\begin{array}{c}0.01 \\
(1.46)\end{array}$ \\
\hline INF & $\begin{array}{c}0.00 \\
(0.45)\end{array}$ & & $\begin{array}{c}0.00 * \\
(1.72)\end{array}$ & $\begin{array}{l}0.00 * * \\
(2.46)\end{array}$ \\
\hline BANCRI & $\begin{array}{l}-0.01 \\
(0.46)\end{array}$ & & $\begin{array}{c}0.03 \\
(0.22)\end{array}$ & \\
\hline EXREG & $\begin{array}{c}-0.02 \\
(0.52)\end{array}$ & & $\begin{array}{c}0.16 \\
(1.33)\end{array}$ & \\
\hline LEFT & $\begin{array}{c}-0.02 \\
(0.54)\end{array}$ & & $\begin{array}{c}-0.04 \\
(0.30)\end{array}$ & \\
\hline DEM & $\begin{array}{c}0.00 \\
(0.42)\end{array}$ & & $\begin{array}{l}-0.03 * * * \\
(2.62)\end{array}$ & $\begin{array}{l}-0.03 * * * \\
(4.04)\end{array}$ \\
\hline ELECT & $\begin{array}{c}0.00 \\
(0.14)\end{array}$ & & $\begin{array}{c}-0.05 \\
(0.42)\end{array}$ & \\
\hline Observations & 152 & 152 & 478 & 705 \\
\hline Sigma & $\begin{array}{c}0.15 \\
(17.44)\end{array}$ & $\begin{array}{c}0.15 \\
(17.44)\end{array}$ & $\begin{array}{c}1.20 \\
(28.68)\end{array}$ & $\begin{array}{c}1.13 \\
(35.48)\end{array}$ \\
\hline DECOMP fit measure & 0.49 & 0.49 & 0.39 & 0.32 \\
\hline
\end{tabular}

Note: Dependent variable for 6.1-6.2 is an ordinal measure of the degree of capital controls ranging from 0 (full controls) to 1 (no controls); see Miniane (2004) for details. Dependent variable for 6.3-6.4 is an ordinal measure of the degree of capital controls ranging from -2.5 (full controls) to +2.5 (no controls); see Chinn and Ito (2007) for details. All specifications estimated with a Tobit methodology. For definitions of all other variables, see Appendix. $T$-statistics in parentheses; significance levels are $10 \% *, 5 \% * *$ and $1 \% * * *$. 
Table 6. The IMF and Capital Controls (Miniane Index)

\begin{tabular}{|c|c|c|c|c|}
\hline & Equation (6.1) & Equation (6.2) & Equation (6.3) & Equation (6.4) \\
\hline CURCR & $\begin{array}{c}-0.04 \\
(0.95)\end{array}$ & $\begin{array}{l}-0.04 \\
(1.04)\end{array}$ & $\begin{array}{c}-0.12 * \\
(1.63)\end{array}$ & $\begin{array}{c}-0.12^{*} \\
(1.63)\end{array}$ \\
\hline $1990 \mathrm{~s}$ & $\begin{array}{l}0.08^{* *} \\
(2.00)\end{array}$ & $\begin{array}{c}-0.03 \\
(0.58)\end{array}$ & $\begin{array}{l}0.08^{* *} \\
(2.05)\end{array}$ & $\begin{array}{l}0.08^{* *} \\
(2.05)\end{array}$ \\
\hline IMF & $\begin{array}{c}0.02 \\
(0.52)\end{array}$ & & & $\begin{array}{c}-0.00 \\
(0.06)\end{array}$ \\
\hline IMF80s & & $\begin{array}{c}-0.09^{*} \\
(1.86)\end{array}$ & & \\
\hline IMF90s & & $\begin{array}{l}0.11 * * \\
(2.47)\end{array}$ & & \\
\hline IMF*CURCR & & & $\begin{array}{c}0.12 \\
(1.43)\end{array}$ & $\begin{array}{c}0.12 \\
(1.34)\end{array}$ \\
\hline IMF*NOCURCR & & & $\begin{array}{c}-0.00 \\
(0.06)\end{array}$ & \\
\hline Observations & 152 & 152 & 152 & 152 \\
\hline Sigma & $\begin{array}{c}0.18 \\
(14.78)\end{array}$ & $\begin{array}{c}0.18 \\
(14.76)\end{array}$ & $\begin{array}{c}0.18 \\
(14.79)\end{array}$ & $\begin{array}{c}0.18 \\
(14.79)\end{array}$ \\
\hline DECOMP fit measure & 0.52 & 0.52 & 0.52 & 0.52 \\
\hline
\end{tabular}

Note: Dependent variable for is an ordinal measure of the degree of capital controls ranging from 0 (full controls) to 1 (no controls); see Miniane (2004) for details. Model estimated with a Tobit methodology. Additional control variables are those of equation (6.2). $T$-statistics in parentheses; significance levels are $10 \% *, 5 \% * *$ and $1 \% * * *$.

The specification we arrive at in equation (5.2) is similar to the one in equation (2.3). However, as discussed before, the estimation in levels has higher explanatory power, as is evident in the substantial number of statistically significant coefficients. These include reserve coverage and trade openness ( - for the Miniane data but + for the Chinn-Ito data), government consumption $(-)$, short-term debt $(-)$, the fiscal surplus $(+)$, per capital GDP (+), the current account (+), and foreign interest rates (-).

Government unity is significant here, again with a negative sign. Democratic regimes are now found to be less likely to have liberalized international capital account in the Chinn-Ito data set. The other controls that were insignificant in Table 2 remain insignificant with both the Miniane and Chinn-Ito data, and are dropped from the specifications reported in Tables 6 and 7. The results in these tables are remarkably similar, even though the dependent variable and sample size are different.

In Table 6, we add variables regarding IMF programs to the benchmark specification for the Miniane data, equation (5.2) of Table 5. In equation (6.1), the IMF variable appears with an insignificant coefficient, while the 1990s variable is positive and significant. In the following equation, we distinguish between IMF programs of the 1980s and those that occurred in the 1990s. The former has a negative coefficient significant at the $10 \%$ level, whereas the latter has a positive coefficient, significant at the $5 \%$ level. These results corroborate our conclusion from equation (4.2) that the IMF had a bigger impact on eliminating capita controls in the 1990s.

In equations (6.3) and (6.4), we introduce the interactive IMF and currency crisis variable that we had used in Table 3. It appears here with a positive coefficient that is insignificant. We conclude we cannot find credible evidence that the IMF's impact on 
Table 7. The IMF and Capital Controls (Chinn-Ito Index)

\begin{tabular}{|c|c|c|c|c|}
\hline & Equation (7.1) & Equation (7.2) & Equation (7.3) & Equation (7.4) \\
\hline CURCR & $\begin{array}{c}-0.26 * * \\
(2.43)\end{array}$ & $\begin{array}{c}-0.25 * * \\
(2.34)\end{array}$ & $\begin{array}{l}-0.42 * * * \\
(2.59)\end{array}$ & $\begin{array}{l}-0.42 * * * \\
(2.59)\end{array}$ \\
\hline 1990s & $\begin{array}{l}0.32 * * * \\
(3.41)\end{array}$ & $\begin{array}{c}0.02 \\
(0.17)\end{array}$ & $\begin{array}{l}0.32 * * * \\
(3.46)\end{array}$ & $\begin{array}{l}0.32 * * * \\
(3.46)\end{array}$ \\
\hline IMF & $\begin{array}{l}-0.12 \\
(1.34)\end{array}$ & & & $\begin{array}{c}-0.17^{*} \\
(1.75)\end{array}$ \\
\hline IMF80s & & $\begin{array}{l}-0.37 * * * \\
(3.23)\end{array}$ & & \\
\hline IMF90s & & $\begin{array}{c}0.22^{*} \\
(1.66)\end{array}$ & & \\
\hline IMF*CURCR & & & $\begin{array}{c}0.11 \\
(0.54)\end{array}$ & $\begin{array}{c}0.28 \\
(1.27)\end{array}$ \\
\hline $\mathrm{IMF}^{*} \mathrm{CURNOCR}$ & & & $\begin{array}{c}-0.17 * \\
(1.75)\end{array}$ & \\
\hline Observations & 705 & 705 & 705 & 705 \\
\hline Sigma & $\begin{array}{c}1.13 \\
(35.48)\end{array}$ & $\begin{array}{c}1.12 \\
(35.48)\end{array}$ & $\begin{array}{c}1.13 \\
(35.48)\end{array}$ & $\begin{array}{c}1.13 \\
(35.48)\end{array}$ \\
\hline DECOMP fit measure & 0.32 & 0.32 & 0.32 & 0.31 \\
\hline
\end{tabular}

Note: Dependent variable is an ordinal measure of the degree of capital controls ranging from -2.5 (full controls) to +2.5 (no controls); see Chinn and Ito (2007) for details. Model estimated with a Tobit methodology. Additional control variables are those of equation (6.4). For definitions of variables, see Appendix. $T$-statistics in parentheses; significance levels are $10 \% *, 5 \% * *$ and $1 \% * * *$.

the existence of capital controls depended on whether the country underwent a financial crisis.

Finally, we use the Chinn-Ito index as the dependent variable, and in equations (5.3) and (5.4) we report the results of estimations with the control variables. In Table 7, we add the program and other variables to the benchmark equation, equation (5.4). The results in the first two equations are identical to those reported in Table 6: the 1990s dummy has a positive significant coefficient, while the IMF program variable for the $1990 \mathrm{~s}$ is again positive and significant at the $10 \%$ level. In equation (7.3), where we again interact the IMF program variable with the crisis and non-crisis variables, the coefficients are not significant.

\section{Initial Conditions and Consequences}

Critics of the IMF have charged that not only did the IMF pressure countries to decontrol the capital account, but that this was done before the countries were ready for capital flows. As a preliminary step in examining this second charge, we determined which liberalization episodes were followed by financial crises in the four years following liberalization. We use the occurrence of sudden stops, i.e., reversals in capital flows, from Honig (2005) to ascertain the dates of financial crises. The liberalization episodes which were followed by crises are marked in Appendix B of the working paper (Joyce and Noy, 2005). Crises do not seem to be any more prevalent among the IMF-led liberalizing countries than in those countries that liberalized without IMF intervention.

To test the "premature liberalization" hypothesis more systematically, we compare the characteristics of countries that decontrolled before and during their participation 
Table 8. Macroeconomic Conditions at Time of Liberalization, With and Without IMF Programs

$$
\text { Year } t-1
$$

Liberalizations with IMF programs

Liberalizations without IMF programs

\begin{tabular}{lrrrrrrrr}
\hline & Mean & Std. dev. & Number & & Mean & Std. dev. & Number \\
\hline CURAC* & -5.51 & 9.22 & 64 & & CURAC* & -2.58 & 7.51 & 58 \\
RES*** & 2.46 & 2.07 & 65 & RES*** & 4.21 & 4.39 & 56 \\
INF & 204.60 & 1422.63 & 68 & INF & 178.26 & 1023.12 & 74 \\
GBUD & -4.31 & 4.52 & 43 & GBUD & -2.76 & 5.45 & 55 \\
\hline
\end{tabular}

Yeart

Liberalizations with IMF programs

Liberalizations without IMF programs

\begin{tabular}{lrrrlrrrr}
\hline & Mean & Std. dev. & Number & & Mean & Std. dev. & Number \\
\hline CURAC & -3.46 & 8.20 & 64 & & CURAC & -2.65 & 8.42 & 64 \\
RES* & 3.02 & 2.31 & 66 & & RES* & 4.07 & 3.90 & 62 \\
INF & 31.36 & 49.39 & 67 & INF & 124.82 & 875.37 & 73 \\
GBUD & -3.27 & 4.69 & 43 & GBUD & -2.66 & 5.30 & 56
\end{tabular}

Note: *,**, and *** indicate whether the means of the variables with and without and IMF program are significantly different at the $10 \%, 5 \%$, and $1 \%$ confidence levels, respectively.

in IMF programs with those that liberalized without the IMF. Table 8 reports the mean values of several macroeconomic indicators for these two groups, in the year before liberalization $(t-1)$, as well as the year of liberalization $(t)$. We used the ChinnIto measurement of capital decontrol to identify the countries that liberalized, as that measurement yielded the largest number of episodes of liberalization.

The countries that decontrolled capital flows during an IMF program, had on average larger current account deficits, smaller reserve coverage, higher inflation, and larger budget deficits in the year before liberalization, than the countries which removed capital account restrictions independently. The average current account deficit in the former group, for example, was $5.5 \%$ of GDP versus $2.6 \%$ for the latter, and this difference is significant at the $10 \%$ level. Reserves covered an average 2.5 months of imports for the IMF group and 4.2 months for those that liberalized without the IMF, and this difference is significant at the $1 \%$ level. Inflation for the first group averaged $204 \%$ versus $178 \%$ for the second, while the government budget showed an average deficit of $-4.3 \%$ of GDP for the IMF group as opposed to $-2.8 \%$ for the independent group. These two pairs of mean values were not significantly different.

However, the countries that decontrolled during participation in IMF programs, showed markedly larger improvements in economic conditions in the year when the program began and capital restrictions were removed. The current account deficit fell to an average $3.5 \%$, and the two means are no longer significantly different. Reserve coverage increased to an average of 3 months in the IMF-affiliated group, while reserve coverage for the second group declined somewhat; the difference is only significant at the $10 \%$ level. The rate of inflation in the group with programs declined to $31.4 \%$, which is substantially lower than the rate of $124.8 \%$ in the non-program 
group. Finally, the government budget deficit came down to $-3.3 \%$ in the group with the programs, while declining only very slightly in the other group. ${ }^{8}$

The countries that liberalized during the IMF programs, therefore, did record adverse macroeconomic conditions before they liberalized. However, the domestic authorities adjusted their policies, apparently in response to the IMF program, and as a result a stronger macroeconomic environment accompanied capital decontrol. There was no immediate adverse impact resulting from the liberalization of the capital account on other macroeconomic indicators. ${ }^{9}$

Another interesting hypothesis is that premature liberalization might lead to the re-imposition of capital controls..$^{10}$ In practice, this appears to be an infrequent occurrence. In Miniane's data set, only one country re-imposed capital controls, Turkey in 1996. This specific case could be associated with the global fallout following the Tequila crisis in Mexico, yet this is a unique event. Even among the East Asian countries most affected by the crisis of 1997-98, only Malaysia changed its capital account policies by imposing some limits on capital outflows, a very public but temporary policy shift.

\section{Conclusions}

The empirical evidence reported in this paper is consistent with the hypothesis that capital account decontrol in developing countries took place within the context of IMF programs, particularly during the 1990s. There is some evidence that the change in the capital account regime was more likely to occur during the IMF's concessionary programs. However, Fund programs were also significant determinants of capital account decontrol in countries with higher incomes that are generally not the typical clients for concessionary loans.

There is also evidence that liberalization was less likely to occur during a currency crisis. In addition, we find little evidence relevant to the accusation that IMF-related liberalization were more likely to occur in countries experiencing a financial crisis; when we interact the IMF program variable with the crisis variable, the nature of the relationship depends on the choice of indicator of capital account openness.

There is nothing in our findings to suggest that countries liberalized against their will. Since capital controls were permissible under the Articles of Agreement, the IMF could not explicitly pressure countries to remove them. Cho (2003), Nasution (2003) and Nidhiprabha (2003), in studies of liberalization in South Korea, Indonesia, and Thailand, found that domestic advocates, including commercial bankers and government economists, were influential in the process of deregulation. The IMF's Independent Evaluation Office (2005, p. 94), in its examination of the IMF's policy stance on this issue, concluded: "In summary, the IMF undoubtedly encouraged countries that wanted to move ahead with capital account liberalization, and even acted as a cheerleader when it wished to do so, especially before the East Asian crisis, but there is no evidence that it exerted significant leverage to push countries to move faster than they were willing to go."

The IMF's decision to advocate decontrol seems to have been taken without placing sufficient emphasis on the necessary financial conditions to ensure stability after capital flows were deregulated. Advocates of decontrol may have thought that these flows would themselves create these conditions. Guitián (1995, p. 85), an advocate of liberalization, wrote "An open capital account will constrain domestic policies to the extent necessary to bring about balance and stability to the economy ..."

In retrospect, those hopes were overly optimistic. The events of 1997 and 1998 caused a reassessment of the benefits and costs of capital flows, and the IMF now has a much 
more nuanced stance on this issue. Prasad et al. (2003), for example, found little evidence that financial globalization was associated with higher output growth, and may have contributed to increased consumption volatility. Another recent paper by the IMF (2002) presented a sequencing methodology that includes macroeconomic stability and financial supervision in the first stage.

The IMF's position on capital controls will continue to evolve as circumstances change. Private capital flows to developing economies increased to a record $\$ 647$ billion in 2006. The movement towards liberalization may have been halted, but it will re-emerge in future years, and the IMF will undoubtedly have a key place in the ensuing discussions.

\section{Appendix: Data}

\begin{tabular}{|c|c|c|}
\hline Variable & Definition & Source \\
\hline BANCRI & Banking crisis & Caprio and Klingebiel (1999) ${ }^{\mathrm{a}}$ \\
\hline CHINITO & $\begin{array}{l}\text { Capital account liberalization index } \\
(-2.5-+2.5)\end{array}$ & Chinn and Ito (2007) \\
\hline CORPT & Corruption & International country risk guide \\
\hline CURAC & Current account ( $\%$ of GDP) & World development indicators \\
\hline CURCR & Currency crisis & Glick and Hutchison (2005) \\
\hline DEM & Democratic regime & Polity $I V$ dataset \\
\hline ELECT & Elections $(0 / 1)$ & Database of political institutions \\
\hline EXREG & Exchange rate regime & $A R E A R$ dataset \\
\hline FINT & Foreign interest rate & International finance statistics \\
\hline GBUD & Government budget surplus & World development indicators \\
\hline GCON & Government consumption ( $\%$ of GDP) & World development indicators \\
\hline GDPCAP & GDP per capita (PPP\$) & World development indicators \\
\hline IMF & IMF program & IMF annual reports \\
\hline IMFSIZE & IMF program size ( $\%$ of GDP) & IMF annual reports \\
\hline INF & Inflation (\% change in CPI) & International finance statistics \\
\hline KAL & Capital account liberalization $(0 / 1)$ & $A R E A R$ dataset \\
\hline LEFT & Left wing executive & Database of political institutions \\
\hline LRIMF & Long-run IMF program (SAF, ESAF) & IMF annual reports \\
\hline MINIANE & Capital account liberalization index $(0-1)$ & Miniane (2004) \\
\hline NEWIMF & New IMF program & IMF annual reports \\
\hline NOCURCR & No currency crisis & Glick and Hutchison (2005) \\
\hline RES & $\begin{array}{l}\text { Foreign exchange reserves (in months of } \\
\text { imports) }\end{array}$ & International finance statistics \\
\hline SRIMF & Short-run IMF program (SBA, EFF) & IMF annual reports \\
\hline STDBT & Short-term debt ( $\%$ of total debt) & World development indicators \\
\hline TRAD & Exports plus imports (\% of GDP) & World development indicators \\
\hline UNITY & Government unity (Herfindhal index) & Database of political institutions \\
\hline
\end{tabular}

${ }^{a}$ Available at www.worldbank.org

\section{References}

Abdelal, Rawi, Capital Rules: The Construction of Global Finance, Cambridge, MA: Harvard University Press (2007).

Abiad, Abdul and Ashoka Mody, "Financial Reform: What Shakes It? What Shapes It?" American Economic Review 95 (2005):66-88. 
Caprio, Gerard and Daniela Klingebiel, "Episodes of Systemic and Borderline Financial Crises," World Bank Research Dataset (1999).

Chinn, Menzie and Hiro Ito, "What Matters for Financial Development? Capital Controls, Institutions, and Interactions," Journal of Development Economics 81 (2006):163-92.

— "Notes on the Calculation of the Chinn-Ito Financial Openness Variable," http:// www.ssc.wisc.edu/ mchinn (2007) (accessed 28 February 2007).

Cho, Yoon Je, "The Political Economy of Financial Liberalization and the Crisis in South Korea," in Chung H. Lee (ed.), Financial Liberalization and the Economic Crisis in Asia, London and New York: Routledge (2003):82-103.

DeLong, Brad and Barry Eichengreen, "Between Meltdown and Moral Hazard: the International Monetary and Financial Policies of the Clinton Administration," in Jeffrey Frankel and Peter Orszag (eds), American Economic Policy in the 1990s, Cambridge, MA: MIT Press (2002):191-263.

Desai, Padma, Financial Crisis, Contagion, and Containment, Princeton, NJ: Princeton University Press (2003).

Edison, Hali J., Michael W. Klein, Luca Antonio Ricci, and Torsten Sløk, "Capital Account Liberalization and Economic Performance: Survey and Synthesis," IMF Staff Papers 51 (2004):220-56.

Eichengreen, Barry, "Capital Account Liberalization: What Do Cross-Country Studies Tell Us?" World Bank Economic Review 15 (2001):341-65.

Glick, Reuven and Michael Hutchison, "Capital Controls and Exchange Rate Instability in Developing Economies," Journal of International Money and Finance 24 (2005):387412.

Grilli, Vittorio and Gian Maria Milesi-Ferretti, "Economic Effects and Structural Determinants of Capital Controls," IMF Staff Papers 43 (1995):517-51.

Guitián, Manuel, "Capital Account Liberalization: Bringing Policy in Line with Reality," in Sebastian Edwards (ed.), Capital Controls, Exchange Rates, and Monetary Policy in the World Economy, Cambridge, UK and New York: Cambridge University Press (1995):71-90.

Haggard, Stephan and Sylvia Maxfield, "The Political Economy of Capital Account Liberalisation," in Helmut Riesen and Bernhard Fischer (eds), Financial Opening: Policy Issues and Experiences in Developing Countries, Paris: OECD (1993):65-83.

- "The Political Economy of Financial Internationalization in the Developing World," International Organization 50 (1996):35-68.

Honig, Adam, "Do Improvements in Government Quality Necessarily Reduce the Incidence of Sudden Stops," manuscript (2005).

Independent Evaluation Office, IMF, Report on the Evaluation of the IMF's Approach to Capital Account Liberalization, Washington, DC: IMF (2005).

International Monetary Fund, Capital Account Convertibility: Review of Experience and Implications for IMF Policies, IMF Occasional Paper No. 131 (1995).

International Monetary Fund, Capital Account Liberalization and Financial Sector Stability, IMF Occasional Paper No. 211 (2002).

Joyce, Joseph and Ilan Noy, "The IMF and the Liberalization of Capital Flows," East-West Center Working Papers, Economics Series, No. 84 (2005).

Leiteritz, Ralf J., "Explaining Organisational Outcomes: the International Monetary Fund and Capital Account Liberalisation," Journal of International Relations and Development 8 (2005):1-26.

Milesi-Ferretti, Gian Maria, "Why Capital Controls? Theory and Evidence," in Sylvester Eijffinger and Harry Huizanga (eds), Positive Policy Economy: Theory and Evidence, Cambridge, UK and New York: Cambridge University Press (1998):217-47.

Miniane, Jacques, "A New Set of Measures on Capital Account Restrictions," IMF Staff Papers 51 (2004):276-308.

Nasution, Anwar, "Financial Sector Reform and Indonesia's Economic Crisis of 1997-98," in Chung H. Lee (ed.), Financial Liberalization and the Economic Crisis in Asia, London and New York: Routledge (2003):47-81. 
Nidhiprabha, Bhanupong, "Premature Liberalization and Economic Crisis in Thailand," in Chung H. Lee (ed.), Financial Liberalization and the Economic Crisis in Asia, London and New York: Routledge (2003):27-46.

Prasad, Eswar S., Kenneth Rogoff, Shang-Jin Wei, and M. Ayhan Kose, Effects of Financial Globalization on Developing Countries: Some Empirical Evidence, IMF Occasional Paper No. 220 (2003).

Quinn, Dennis P., "Capital Account Liberalization and Financial Globalization, 1890-1990: a Synoptic View," International Journal of Finance and Economics 8 (2003):189-204.

Rowlands, Dane, "IMF Resource Management in a World of Mobile Capital," Canadian Journal of Development Studies 20 (1999):465-87.

Simmons, Beth A. and Zachary Elkins, "The Globalization of Liberalization: Policy Diffusion in the International Political Economy," American Political Science Review 98 (2004):171-89.

Stiglitz, Joseph E., Globalization and Its Discontents, New York and London: W. W. Norton (2002).

Williamson, John, "What Washington Means by Policy Reform," in John Williamson (ed.), Latin American Adjustment: How Much has Happened? Washington, DC: Institute for International Economics (1990):7-28.

\section{Notes}

1. See Quinn (2003) for an overview of the record of capital account liberalization.

2. According to the IMF (1995), it began to encourage capital account convertibility in the mid-1980s.

3. Precautionary programs, which are signed to have an agreement in place should a country require the funds, are included in our definition. In addition, in some cases disbursements beyond the first tranche are not made because they are no longer necessary, or the IMF decides its conditionality has not been met. In either case, we include these in our list of programs.

4. A thorough description of this data and a comprehensive discussion of alternative measures are found in Edison et al. (2004), particularly Table 1, p. 224-5.

5. Results are available from the authors.

6. The results for the control variables are available from the authors.

7. We also used three different measurements of political crisis. In a few cases, we found a significant negative coefficient, consistent with the finding that crises lead to more controls. However, these results (available from the authors) were not robust to alternative specifications. 8. We also analyzed the financial systems in the two groups of countries. The results, available in Joyce and Noy (2005), show few noticeable differences.

9. A comprehensive analysis of economic performance and crisis occurrence ex-post capital decontrol, including an accounting for differing policy choices with and without IMF programs, is beyond the scope of this paper, and represents a focus of future research. Major issues include possible policy changes associated with IMF participation, crisis identification, infrequent crisis occurrence, and selection bias.

10. We thank the anonymous referee for pointing out this possibility. 